Original Article

\title{
Serum prolactin and gonadotropin levels in women with infertility in Bangladesh
}

\author{
Shamima Bari ${ }^{1}$, Rokeya Begum ${ }^{2}$ and Qazi Shamima Akter ${ }^{2}$ \\ ${ }^{1}$ Department of Physiology, Ibrahim Medical College, Dhaka \\ ${ }^{2}$ Department of Physiology, Dhaka Medical College, Dhaka
}

\begin{abstract}
Background and objectives: Infertility is a global health problem including Bangladesh. Altered prolactin, follicle (FSH) and luteinizing hormones $(\mathrm{LH})$ levels have been implicated as a cause of infertility. The present study was undertaken to find out the serum prolactin and gonadotropin levels in women with primary and secondary infertility.

Methods: The study involved a total of 100 women of which 50 had primary (Group A) and another 50 had secondary (Group B) infertility. Fifty fertile age-matched women were included as control (Group C). All the study participants were selected from women attending the infertility unit of Bangabandhu Sheikh Mujib Medical University (BSMMU), Dhaka. Serum prolactin, FSH and LH hormones were measured by radioimmunoassay with blood collected on the 2nd day of menstrual cycle.

Results: The mean serum prolactin level was significantly higher $(<\mathrm{p} 0.01)$ while the mean serum FSH and LH levels were significantly $(\mathrm{p}<0.01)$ lower in women with primary and secondary infertility compared to fertile women. However, the mean serum prolactin, FSH and LH levels were not significantly different from each other among the women with primary and secondary sterility. High prolactinemia was observed in $16 \%$ and $14 \%$ women in Group A and B respectively.

Compared to women with secondary sterility, significantly $(\mathrm{p}<0.05 \%)$ higher number of cases with primary sterility (30\% vs. 54\%) had FSH level below the normal range. On the other hand, $28 \%$ cases with secondary sterility had LH level below the normal range compared to $10 \%$ in primary sterility group $(\mathrm{p}<0.05)$.
\end{abstract}

Conclusion: The study has demonstrated that there was alteration of serum prolactin, FSH and LH levels in women with primary and secondary sterility.

IMC J Med Sci 2018; 12(1): 01-05

\section{Introduction}

Infertility is a worldwide reproductive health issue including Bangladesh. It affects approximately 10 to $15 \%$ couples and more than 80 million people worldwide [1-3]. In Bangladesh, the rate of infertility has been reported as $4 \%$ to $15 \%$ [4-7]. The causes of infertility include ovarian (30 - 40 $\%$ ), cervical (5\%), and male (25-40\%) factors while $10-15 \%$ has unexplained causes $[4,5]$.

Hormonal disorders of female reproductive system occur due to aberrant dysfunction of hypo-thalamic- pituitary-ovarian axis and are relatively common disorders leading to infertility. The increased or decreased levels of prolactin, FSH and LH hormones may cause infertility [8-10]. High level of prolactin may cause infertility affecting FSH and gonadrotropin releasing hormone $(\mathrm{GnRH})$ [11]. High prolactin level inhibits GnRH and follicle stimulating hormone leading to infertility [12-16].

Therefore, the present study was undertaken to measure the serum prolactin, FSH and LH levels in women with primary and secondary infertility.

Address for Correspondence:

Dr. Shamima Bari, Assistant Professor, Department of Physiology, Ibrahim Medical College, 122 Kazi Nazrul Islam Avenue, Shahbag, Dhaka.E-mail: shamima.bari@yahoo.com 


\section{Methods}

This cross sectional study was carried out in the department of Physiology, Dhaka Medical College, Dhaka from July 2010 to June 2011 and the protocol was approved by Ethical Review Committee of Dhaka Medical College.

Study design: Women with infertility, attending the Infertility Unit of Bangabandhu Sheikh Mujib Medical University (BSMMU) were included in the study. Women with infertility were further divided into primary and secondary infertility groups. Primary and secondary infertility groups were denoted as Group A and B respectively. Equal number of age matched apparently healthy fertile women were enrolled as control and denoted as Group C. Infertility was defined as the inability of couple to achieve conception after one year of frequent unprotected intercourse without contraception [17]. Primary infertility denoted those women who had never conceived. Secondary infertility or sterility was defined as the same condition developing after initial phase of fertility that means conceived previously but failed to conceive subsequently [18]. The fertility was defined as the capacity to conceive.

Infertile women having husbands with normal semen analysis results and normal genitalia, uterus and adnexa were included. Women with tubal factor, congenital anomaly of urogenital tract and any obvious organic lesion or pelvic inflammatory diseases, and lactating women were excluded from this study. The purpose and benefits of the study were explained to each participant and informed written consent was taken from each of them. A detailed personal, medical, family, socio-economic and drug history were recorded in a predesigned questionnaire.

Anthropometric measurements: Body weight and height were measured in kilogram $(\mathrm{kg})$ and in centimeters respectively. The Body Mass index (BMI) was calculated by using the formula: weight in kilograms / (height in meters).

Biochemical parameters and collection of blood: Aseptically 5 milliliter of blood was collected from medial cubital vein from each participant in the 2nd day of menstrual cycle. Blood was allowed to clot for 30-60 minutes at room temperature and then centrifuged at $3000 \mathrm{rpm}$ for 5-10 minutes and serum was separated and preserved at $-20^{\circ} \mathrm{C}$ for estimation of serum prolactin, FSH and $\mathrm{LH}$. Prolactin, FSH and LH were measured by radioimmunoassay at the Centre for Nuclear Medicine and Ultrasound, Dhaka Medical College. The analysis was done within 2 weeks of blood collection. The normal range for prolactin, FSH and $\mathrm{LH}$ were $2-25 \mathrm{ng} / \mathrm{dl}, 3.1-7.9 \mathrm{IU} / \mathrm{L}$ and $1.9-$ $12.5 \mathrm{IU} / \mathrm{L}$ respectively.

Statistical Analysis: The data were analyzed by appropriate statistical tests namely, one way ANOVA, Tukey's HSD post-hoc test and student's $\mathrm{t}$ tests and $\mathrm{Z}$ test.

\section{Results}

A total of 150 women were included in the study. Out of 150 enrolled participants, 50 had primary and another 50 had secondary infertility. Fifty age matched apparently healthy fertile women were enrolled as control. Mean age of different groups of study population were almost similar and no statistically significant difference was observed among the study groups (Table-1). The mean BMI of women with primary (group A: 28.05 \pm 4.08 $\mathrm{kg} / \mathrm{m}^{2}$ ) and secondary infertility (group B: $27.62 \pm 3.68 \mathrm{~kg} / \mathrm{m}^{2}$ ) were significantly higher $(\mathrm{p}<0.01)$ compared to fertile women (group $\mathrm{C}$ : $25.35 \pm 3.48 \mathrm{~kg} / \mathrm{m}^{2}$ ). There was no significant difference of BMI between group A and B.

Table-1: Age and body mass index (BMI) of study population

\begin{tabular}{lccc}
\hline $\begin{array}{c}\text { Study } \\
\text { population }\end{array}$ & Number & $\begin{array}{c}\text { Age (years) } \\
\text { Mean } \pm \text { SD }\end{array}$ & $\begin{array}{c}\text { BMI } \\
\left(\mathbf{k g} / \mathbf{m}^{\mathbf{2}}\right) \\
\text { Mean } \pm \text { SD }\end{array}$ \\
\hline Group A & 50 & $27.08 \pm 4.15$ & $28.05 \pm 4.08$ \\
Group B & 50 & $28.98 \pm 4.81$ & $27.62 \pm 3.68$ \\
Group C & 50 & $27.82 \pm 4.65$ & $25.35 \pm 3.48$ \\
\hline
\end{tabular}

Note: $G r A=$ Primary sterility, $G r B=$ Secondary sterility, $\mathrm{GrC}=$ women with normal fertility (Control); One way ANOVA and Tukey's post-hoc tests were performed to compare among the groups. Age - GrA vs G C: $p=0.7918, \quad G r C$ vs GrB: $p=0.4372$, GrA vs GrB: $p=0.2375$. BMI- GrA vs GrC: $p=0.0118, \quad G r B$ vs $G r C: p=0.0071, G r A$ vs GrB: $p=0.8882$.

The mean serum prolactin, FSH and LH levels of group $\mathrm{A}, \mathrm{B}$ and $\mathrm{C}$ are shown in Table-2. The mean 
serum prolactin levels of women with primary $(14.54 \pm 8.68 \mathrm{ng} / \mathrm{dl})$ and secondary $(15.36 \pm 7.24)$ infertility were significantly $(\mathrm{p}<0.01)$ higher than that of women with normal fertility $(10.58 \pm 5.01)$. However, the mean serum prolactin level of women with primary and secondary infertility was almost similar. Overall mean serum FSH and LH levels of women with primary and secondary infertility were significantly $(p<0.01)$ low compared to the control group (Table-2).

Table-2: Serum prolactin, FSH and LH levels of study population

\begin{tabular}{ccccc}
\hline \multirow{2}{*}{$\begin{array}{c}\text { Study } \\
\text { population }\end{array}$} & No. & \multicolumn{3}{c}{ Mean $( \pm$ SD) serum levels of } \\
\cline { 3 - 5 } & & $\begin{array}{c}\text { Prolactin } \\
\text { (ng/dl) }\end{array}$ & $\begin{array}{c}\text { FSH } \\
\text { (IU/L) }\end{array}$ & $\begin{array}{c}\text { LH } \\
(\text { IU/L) }\end{array}$ \\
\hline Group A & 50 & $14.54 \pm 8.68$ & $3.73 \pm 2.03$ & $4.86 \pm 3.15$ \\
Group B & 50 & $15.36 \pm 7.24$ & $4.66 \pm 2.23$ & $3.47 \pm 2.03$ \\
Group C & 50 & $10.58 \pm 5.01$ & $6.48 \pm 3.83$ & $8.37 \pm 5.16$ \\
\hline
\end{tabular}

Note: $G r A=$ Primary sterility, $G r B=$ Secondary sterility, $\mathrm{GrC}=$ Control; One way ANOVA and Tukey's post-hoc tests were performed to compare among the groups. Prolactin- GrA vs GrC: $p=0.017$, GrB vs GrC: $p=0.003 ;$ GrA vs GrB: $p=0.834$. FSH - GrA vs GrC: $p=0.001, \quad G r B$ vs $G r C$ : $p=0.004$, GrA vs GrB: $p=0.227$. LH- GrA vs GrC: $p=0.001$, GrB vs GrC: $p=0.001$, GrA vs Gr B: $p=0.145$

Out of 50 cases of primary infertility, $84 \%$ had normal and $16 \%$ had high prolactin level $(>25$ $\mathrm{ng} / \mathrm{dl})$. The rate was $86 \%$ and $14 \%$ respectively in secondary infertility cases. Only 2 cases $(4 \%)$ with normal fertility had high prolactin level. In women with primary sterility, the serum FSH and $\mathrm{LH}$ levels were lower than the normal levels in $54 \%$ and $10 \%$ cases respectively while in secondary sterility the levels were low in $30 \%$ and $28 \%$ cases respectively. Compared to women with secondary sterility, significantly $(p<0.05 \%)$ higher number of cases with primary sterility (30\% vs. $54 \%)$ had FSH level below the normal range (Table-3). On the other hand, compared to primary sterility group significantly higher number of cases with secondary sterility (10\% vs $28 \%)$ had LH level below the normal range.

In primary sterility group, the mean serum prolactin level of women with normal and hyperprolactinemia were $11.73 \pm 4.98 \mathrm{ng} / \mathrm{dl}$ and $31.73 \pm 6.58 \mathrm{ng} / \mathrm{dl}$ respectively and in secondary sterility group the values were $13.12 \pm 3.7 \mathrm{ng} / \mathrm{dl}$ and $29.5 \pm 3.88 \mathrm{ng} / \mathrm{dl}$ respectively $(\mathrm{p}<0.01$; Table4). The mean FSH and LH levels in those cases were significantly low compared to women with normal fertility $(\mathrm{p}<0.05)$.

\section{Discussion}

Hormone levels in women with infertility have been evaluated by many researchers. High prolactin level has been reported as the cause of female infertility $[12,13]$. In the present study, the overall mean serum prolactin level was significantly higher in infertile women than that of control fertile women. However, only $14-16 \%$ women with primary and secondary infertility had prolactinemia above the recommended normal range. Similar observation was also reported by other investigators from different countries [16,19-24]. In the present study, the observation of high prolactinemia in $30 \%$ women with primary and secondary infertility in our study is in agreement with other studies elsewhere [15,25-29]. High prolactinemia is the commonest biochemical abnormality observed in infertility [28]. Furthermore, prolactin may affect the ovaries by altering ovarian progesterone secretion and estrogen

Table-3: Distribution of serum prolactin, FSH and LH levels of study population

\begin{tabular}{|c|c|c|c|c|c|c|}
\hline \multirow{3}{*}{$\begin{array}{c}\text { Study } \\
\text { population }\end{array}$} & \multicolumn{2}{|c|}{ Serum PRL (ng/dl) } & \multicolumn{2}{|c|}{ Serum FSH level (IU/L) } & \multicolumn{2}{|c|}{ Serum LH level (IU/L) } \\
\hline & $\begin{array}{c}\text { Normal } \\
(2-25)\end{array}$ & $\begin{array}{c}\text { High } \\
(>25)\end{array}$ & $\begin{array}{l}\text { Normal } \\
(3.1-7.9)\end{array}$ & $\begin{array}{c}\text { Below normal } \\
(<3.0)\end{array}$ & $\begin{array}{c}\text { Normal } \\
(1.9-12.5)\end{array}$ & $\begin{array}{c}\text { Below normal } \\
(<1.9)\end{array}$ \\
\hline & $\mathrm{N}(\%)$ & $\mathrm{N}(\%)$ & $\mathrm{N}(\%)$ & $\mathbf{N}(\%)$ & $\mathbf{N}(\%)$ & $\mathbf{N}(\%)$ \\
\hline $\begin{array}{l}\text { Group A } \\
(n=50)\end{array}$ & $42(84 \%)$ & $08(16 \%)$ & $23(46 \%)$ & $27(54 \%)$ & $45(90 \%)$ & $5(10 \%)$ \\
\hline $\begin{array}{l}\text { Group B } \\
(\mathrm{n}=50)\end{array}$ & $43(86 \%)$ & $07(14 \%)$ & $35(70 \%)$ & $15(30 \%)$ & $36(72 \%)$ & $14(28 \%)$ \\
\hline $\begin{array}{l}\text { Group C } \\
(\mathrm{n}=50)\end{array}$ & $48(96 \%)$ & $02(0 \%)$ & $45(90 \%)$ & 05 & 50 & 0 \\
\hline
\end{tabular}

Note: Normal serum levels of (a) prolactin=2-25 $\mathrm{ng} / \mathrm{dl}$, (b) FSH=3.1-7.9 IU/L, and (c) LH=1.9 - $12.5 \mathrm{IU} / \mathrm{L}$ during follicular phase. GrA vs GrB: $L H-Z=2.2942, p=0.02 ; F S H-Z=2.4313, p=0.02$; Prolactin- $Z=0.280, p=0.779$. 
synthesis leading to infertility $[27,28]$. Women with high level of prolactin may ovulate regularly but may not produce enough progesterone during luteal phase after ovulation. Deficiency of progesterone produced after ovulation, may hamper embryo implantation in a uterine lining [30,31].

Table-4: Levels of serum prolactin, FSH and LH in women with normal and high prolactinemia in different groups of study population

\begin{tabular}{lcccc}
\hline \multicolumn{1}{c}{$\begin{array}{c}\text { Study } \\
\text { population }\end{array}$} & \multirow{2}{*}{$\begin{array}{c}\text { No. } \\
(\%)\end{array}$} & \begin{tabular}{c} 
Mean \pm SD serum level of \\
\cline { 3 - 5 }$(\mathbf{n g} / \mathbf{d l})$
\end{tabular} & $\begin{array}{c}\text { FSH } \\
\text { (IU/L) }\end{array}$ & $\begin{array}{c}\text { LH } \\
(\mathbf{I U} / \mathbf{L})\end{array}$ \\
\hline $\begin{array}{l}\text { Gr A-Primary } \\
\text { infertility (n=50) }\end{array}$ & & & & \\
Normal PR level & $42(84)$ & 11.73 & 3.7 & 4.95 \\
& & \pm 4.9 & \pm 3.6 & \pm 2.5 \\
High PR Level & $8(16)$ & 31.73 & 4.73 & 4.2 \\
& & \pm 6.6 & \pm 1.9 & \pm 2.6 \\
Gr B- Secondary & & & & \\
infertility (n=50) & & & & \\
Normal PR level & $43(86)$ & 13.12 & $4.87 \pm$ & 3.4 \\
& & \pm 3.7 & 2.9 & \pm 3.7 \\
High PR level & $7(14)$ & 29.5 & 3.3 & 3.8 \\
& & \pm 3.9 & \pm 1.4 & \pm 2.8 \\
Gr C- Control & & & & \\
Normal PR level & 50 & 10.58 & 6.48 & $8.37 \pm$ \\
& & \pm 5.0 & \pm 3.8 & 5.2 \\
High PR level & 0 & - & - & - \\
\hline
\end{tabular}

Note: $P R=$ Prolactin; High prolactinemia $>25 n g / d l) ; p<0.05$ when compared for FSH and LH between: $G r A$ and $G r C$; $G r B$ and $\mathrm{GrC}$ with high PR levels.

Higher than the normal range of FSH and $\mathrm{LH}$ is rarely found in infertile women with a proper menstrual cycle but lower concentrations of these hormones have been observed [32]. In this study low levels of gonadotrophins (LH and FSH) were observed in $84 \%$ and $38 \%$ respectively among total infertile women. Similar observation has been reported by others [33]. Serum FSH was significantly lower in primary infertile women than those of secondary infertile women. On the other hand, serum LH was significantly lower in secondary infertile women than that of primary infertile women. A serum level of FSH and $\mathrm{LH}$, below the normal range, during the follicular phase indicates defect in factors that are responsible for their production leading to a poor ovarian reserve and infertility. These could be due to defects in the pituitary gland, GnRH or the hypothalamus [19].

Therefore, the present study has demonstrated that a significant number of women with primary and secondary infertility have altered prolactin, FSH and LH levels compared to fertile women.

\section{Acknowledgement}

We are thankful to the Infertility Unit, Department of Gynecology and Obstetrics, BSMMU for their cooperation. We acknowledge the support of Dr. Sanwar Hossain, Director, Centre for Nuclear Medicine and Ultrasound, Dhaka Medical College, for providing the laboratory facility for biochemical assays. Authors are thankful to all the study participants for their active support.

\section{References}

1. Momtaz H, Flora MS, Shirin S. Factors associated with secondary infertility. Ibrahim Med Coll J. 2011; 5(1): 17-2.

2. Ali T, Sami N, Khuwaja A. Are unhygienic practices during the menstrual, partum and postpartum periods risk factors for secondary infertility? J Health Pop Nutr. 2007; 25(2): 189-194.

3. Safarinejad R. Infertility among couples in a population based study in Iran: prevalence and associated risk factors. Int J Andrology. 2007; 31: 303-314.

4. Vaessen M. Childlessness and infecundity. WFS comparative studies. Series 31. Voorburg, Netherlands: Cross National Summaries.1984.

5. Farely TMM, Baisey EM. The prevalence of an etiology of infertility. Proceedings, The $1^{\text {st }}$ African Population Conference. 1998; Senegal, Dakar, 1998.

6. Nahar P. Invisible women in Bangladesh: stakeholder's view on infertility services. $F V V$ in OBGyn. 2012; 4(3): 149-156.

7. Bangladesh Institute of Research for Promotion of Essential and Reproductive Health and Technologies (BIRPERHT), Briefing paper on Assessment of Reproductive Health Care needs and Review of Services provided at the level of Thana, Union and Village, Dhaka, Bangladesh, 1997; 5: 1-4.

8. Saxema BB and Demura HM. Determination of FSH. J Clin Endocrinol Metab. 1968; 28: 591.

9. Roupa Z, Polikandrioti M, Sotiropoulou P, Faros E, Koulouri A, Wozniak G. Causes of infertility in women at reproductive age. Health Sci J. 2009; 3: 80-7. 
10. Scott MG, Ladenson JH, Green ED, Gast MJ. Hormonal evaluation of female infertility and reproductive disorders. Clin Chem.1989; 35(4): 620-9.

11. Rajan R. Prolactin metabolism in infertility. $J$ Obstet Gynecol India. 1990; 40: 243-7.

12. Avasthi K, Kaur J, Shweata G, Pal AN. Hyperprolactinemia and its correlation with hypothyroidism in infertile woman. J Obs Gyn India. 2007; 56(1): 68-71.

13. Mishra R, Baveja R, Gupta V et al. Prolactin level in infertility with menstrual irregularities. J Obs Gyn India. 2002; 52:40-43.

14. Choudhary SD, Goswami A. Hyperprolactinemia and reproductive disorders - a profile from north east. J Assoc Phy IndiaO. 1995; 43: 617-8.

15. Akhter N, Hassan, MA. Subclinical hypothyroidism and hyperprolactinaemia in infertile women: Bangladesh perspective after universal salt iodinisation. The internet $J$ Endocrinol. 2009; 5(1): 1-5.

16. Emokpae MA, Osadolor HB, Omole Ohonsi A. Sub-clinical hypothyroidism in infertile Nigerian women with hyperprolactinaemia $\mathrm{Nig}$ J Physiol Sci. 2011; 26: 35 - 38.

17. Te Velde ER, Eijkemans R, Habbema HD. Variation in couple fecundity and time to pregnancy, an essential concept in human reproduction. Lancet. 2000; 355: 1928-1929.

18. Peterson BD, Gold L, Feingold T. The experience and influence of infertility: considerations for couple counselors. Fam J. 2007; 15(3): 251-257.

19. Iris A, Kawuwa MB, Habu SA, Adebayo A. Prolactin levels among infertile women in Maiduguri, Nigeria. Trop J Obs Gyn. 2003; 20: $97-100$.

20. Del Pozo E, Wyss H, Tollis G, Alcaniz J, Campana A, Naftolin F. Prolactin and deficient luteal function. Obs Gyn.1979; 53(3): 282-286.

21. Hull MG, Glazener CM, Kelly HJ, Conway DI, Foster PA, Hinton RA. Population study of causes, treatment and outcome of infertility. Br Med J. 1985; 291: 1693-1697.

22. Azima K, Samina J. Role of hyperprolactinemia in fertility. Pakistan J Med. 2002; 3: 41.
23. Parijatham S, Saikumar P. Serum levels of follicle stimulating hormone, luteinizing hormone and prolactin in primary female infertility in rural population. Res J Pharm Bio Chem Sci. 2014; 5(2): 1155-1158.

24. Goswami B, Patel S, Chatterjee M, Koner BC, Saxena A. Correlation of prolactin and thyroid hormone concentration with menstrual patterns in infertile women. J Reprod Infertil. 2009; 10(3): 207-212.

25. Mancini T, Casanueva FF, Giustina A. Hyperprolactinemia and prolactinomas. Endocrinol Metab Clin North Am. 2008; 37(1): 67-69.

26. Kuku SF. African endocrine infertility: a review. Afr J Med sci. 1995; 24: 111-123.

27. Imade GE. Towobola OA, Pam IC, et al. Hyperprolactinaemia and luteal phase progesterone levels amongst infertile Nigerian women. Trop J Obstet Gynaecol. 1998; 15: 52-57.

28. Audu I, Mohammed BK, Adebayo AE. Prolactin levels among infertile women in Maiduguri, Nigeria. Trop J Obstet Gynaecol. 2003; 20(2): 97-100.

29. Emokpae MA, Uadia PO, Mohammed AZ. Hormonal evaluations and endometrial biopsy in infertile women in Kano, northern Nigeria: A comparative study. Annals Afr Med. 2005; 4(3): 99-103.

30. Akande AA Idowu AA, Jimoh AK. Biochemical infertility among females attending University of Ilorin teaching hospital, Nigeria. Niger J Clin Pract. 2009; 12(1):20-24.

31. Prasad B, Parmar D, Sharma NA. Study of serum FSH, LH and prolactin levels among infertile women. Int J Med Res Health Sci. 2015; 4(4): 876-878.

32. Moltz L, Leidenberger F, Weise C. Rational hormone diagnosis in normocyclic functional sterility. J Infertility. 1991; 51(9);756-68.

33. Olooto WE, Adeleye AO, Amballi AA, Mosuro AO. Pattern of reproductive hormones (follicle stimulating hormone, luteinizing hormone, estradiol, progesterone, and prolactin) levels in infertile women in Sagamu South Western Nigeria. Der Pharmacia Lettre. 2012; 4(2): 549-53. 